\title{
THE SEVERITY OF NON-ALCOHOLIC FATTY LIVER IN TYPE II DIABETES
}

\author{
Ovidiu Paul Calapod, Andreea Maria Marin, Laura Carina Tribus, \\ Carmen Fierbințeanu-Braticevici \\ Emergency University Hospital Bucharest
}

\begin{abstract}
Nonalcoholic fatty liver disease (NAFLD) is a chronic liver disease that affects up to one third of the adult population of industrialized countries. The pathophysiological spectrum includes the following entities that are clinically and histologically distinct: hepatic steatosis and steatohepatitis; their subsequent evolution can lead to cirrhosis and hepatocellular carcinoma.

The increase of the prevalence of NAFLD during the last decade is caused by the epidemiological and pathophysiological association with type II diabetes and obesity, NAFLD being present in about $70-80 \%$ of patients with type II diabetes mellitus. It has long been thought that the relationship between type II diabetes mellitus and NAFLD is unidirectional, fatty liver being secondary to insulin resistance and type II diabetes mellitus, but recent studies show that hepatic steatosis may precede insulin resistance and diabetes mellitus, thus demonstrating a bidirectional causal relationship between these two disorders. Weight loss through diet and exercise is effective in preventing and treating NAFLD in diabetic patients; also, drugs that cause weight loss need to be evaluated. Both anti-diabetic medication and statins play an important role in the prevention and treatment of NAFLD.
\end{abstract}

Keywords: nonalcoholic fatty liver disease_hepatic steatosis, steatohepatitis, cirrhosis, hepatocellular carcinoma, diabetes, insulin resistance.

\section{Rezumat}

Boala ficatului gras non-alcoolic reprezintă o boală cronică hepatică care poate afecta până la o treime din populația adultă a țărilor industrializate. Spectrul fiziopatologic cuprinde următoarele entități distincte din punct de vedere clinic și histologic: steatoza hepatică simplă și steatohepatita, cu evoluție ulterioară spre ciroză și carcinom hepatocelular.

Creşterea prevalenţei bolii ficatului gras non-alcoolic în ultimul deceniu este datorată asocierii epidemiologice şi fiziopatologice cu diabetul zaharat tip II şi cu obezitatea, el fiind prezent la aproximativ $70-80 \%$ din pacienții cu diabet zaharat tip II. Mult timp s-a crezut că relaţia dintre diabetul zaharat tip II şi boala ficatului gras non-alcoolic este una unidirecţională, încărcarea grasă a ficatului fiind secundară rezistenței la insulină și diabetului zaharat tip II, dar ultimele studii arată că steatoza hepatică poate precede rezistenţa la insulină si diabetul zaharat, 


\section{INTERNAL}

\section{General Reviews}

demonstrând astfel o relaţie cauzală bidirecţională între aceste două patologii. Scăderea ponderală prin dietă și exercițiul fizic sunt eficiente în prevenția și tratarea bolii ficatului gras nonalcoolic la pacienții diabetici, iar medicamentele ce favorizează scăderea ponderală urmează a fi evaluate. Atât medicația antidiabetică pentru controlul glicemiei cât și statinele joacă un rol important în prevenția și tratamentul bolii ficatului gras non-alcoolic.

Cuvinte cheie: ficatul gras non-alcoolic, steatoza hepatica, steatohepatită, ciroză, carcinom hepatocelular, diabet zaharat, rezistenţa la insulin.

\section{Epidemiology}

The interest in non-alcoholic fatty liver disease (NAFLD) arose about three decades ago, when Ludwig et al. (1) described liver disease not sufficiently understood and not having a name. The reference group consisted of 20 patients with a histological appearance reminiscent of the alcoholic hepatitis with a potential evolution towards cirrhosis, which gave the name of the observed aspect: nonalcoholic steatohepatitis. Already then it has been highlighted that non-alcoholic steatohepatitis is a condition directly related to obesity and diabetes; the most common presentation is hepatomegaly and elevations of liver enzymes.

\section{Prevalence}

NAFLD is the most common hepatic disease in industrialized Western countries, with a globally reported prevalence of $6-35 \%$ (median 20\%) ${ }^{(2)}$. In Europe, the median prevalence is $25-26 \%{ }^{(3)}$ with wide variations by population.

\section{Risk factors. The importance of type II diabetes}

NAFLD's major risk factors are identical to the components of the metabolic syndrome: central obesity, type II diabetes, dyslipidemia, and insulin resistance. Currently, NAFLD is considered "de facto" to be the hepatic component of the metabolic syndrome ${ }^{(4)}$.

However, the increase in NAFLD prevalence over the past decade is due to epidemiological and pathophysiological association with type II diabetes and obesity. The prevalence of NAFLD in obese and diabetic adults exceeds $70 \%{ }^{(5)}$. Also, type II diabetes and obesity are directly associated with NAFLD and are involved in worsening the progression of other aggressive liver diseases. For example, patients with hepatitis $C$ virus and diabetes 
have much higher rates of progression to cirrhosis and hepatocellular carcinoma ${ }^{(6,7)}$.

\section{The bidirectional pathophysiological relationship}

NAFLD includes a spectrum of liver disorders such as simple liver steatosis, steatohepatitis, fibrosis and cirrhosis. Simple hepatic steatosis is the consequence of the accumulation of triglycerides in liver cells in the presence of insulin resistance, and occurs frequently as part of the metabolic syndrome ${ }^{(8)}$.

Non-alcoholic steatohepatitis is a severe manifestation of NAFLD, consisting not only of steatosis, but also involving the presence of inflammatory infiltrate, cellular destruction and fibrosis. Non-alcoholic steatohepatitis is the entity that can progress to cirrhosis, and is currently recognized as the most common cause of cryptogenic cirrhosis $^{(9)}$.

All these things materialize in a pathology where, until the 1990s, the scientific world believed that the relationship between type II diabetes and NAFLD was unidirectional, fatty liver loading being secondary to insulin resistance and type II diabetes. Last year, the results of a large 5-year follow-up study, which included a cohort of 31,000 participants, were published, showing that liver steatosis may precede insulin resistance and diabetes, thus demonstrating a bidirectional causal relationship between NAFLD and diabetes ${ }^{(10)}$.

a. Hepatic fibrosis - consequence of Type II diabetes

The mechanisms by which type II diabetes causes hepatic fibrosis are complex and have been studied in isolated biological systems. It has been highlighted that fatty liver loading, obesity and insulin resistance act as synergistic factors in hepatic impairment ${ }^{(11)}$. By far, the main pathophysiological mechanism involved is insulin resistance. The consequence of this mechanism is the intracellular accumulation of triglycerides due to an increased uptake of free fatty acids and de novo lipogenesis in hepatocytes. Also, there is a reduction in hepatic secretion of VLDL. Increased mitochondrial oxidative stress with the generation of free radicals and peroxisomes leads to hepatic lesions represented by cellular necrosis and inflammation $^{(12)}$.

The adipokines that have been secreted in excess by adipocytes such as leptin and TNF- $\alpha$ play a role in the production of oxidative stress. All of this pro-inflammatory cytokine storm, as well as chemical mediators resulting from cellular destruction, activate hepatic stellate cells with a secondary increase of collagen production and of connective tissue growth factors, and extracellular matrix accumulation, with an evolution towards liver cirrhosis.

\section{b. Type II diabetes - a consequence of chronic liver diseases}

Depending on the etiology, the degree of hepatic impairment and the diagnostic criteria, the reported incidence of glucose intolerance varies between $70-85 \%$, and of diabetes mellitus between $40-60 \%{ }^{(13)}$. Since the early stages of chronic liver disease, insulin resistance and glucose intolerance have been found in the vast majority of these patients ${ }^{(14)}$. Diabetes mellitus is manifested as liver function is deteriorating, and is considered an indicator of advanced liver disease.

The mechanisms of hepatogenic diabetes are complex and imprecisely known. Resistance to insulin in peripheral tissues (adipose and muscle tissue) plays a central role in the imbalance of glucose metabolism. It has been suggested as a pathophysiological hypothesis that reducing insulin extraction by the affected liver and portosystemic shunts 


\section{INTERNAI}

\section{General Reviews}

causes a hyperinsulinemia which is potentiated by increased levels of anti-insulin hormones (glucagon, growth hormone, insulin-like growth factor), and the suspected increase in glucose sensitivity of pancreatic beta cells. Finally, diabetes develops as a progressive deterioration of insulin secretion with the development of hepatic resistance to insulin, leading to fasting hyperglycemia and a glucose intolerance profile ${ }^{(15)}$.

\section{NAFLD diagnosis}

In clinical practice, NAFLD currently remains a diagnostic of exclusion, and the lack of positive diagnostic criteria is a challenge.

In practical, operational terms, the clinician must follow four steps in the NAFLD assessment. Firstly, an excess of steatose content in the liver should be identified using a series of imaging techniques (abdominal ultrasound) or, in some cases, hepatic biopsy, which remains the reference standard for diagnosis, but also a method far away from the ideal. Secondly, the clinician must exclude the alcoholic, viral, pharmacological, autoimmune or genetic cause of steatosis liver disease. Thirdly, it is necessary to evaluate the presence of other components of the metabolic syndrome, which has already been demonstrated in the evaluation of diabetic patients. Fourthly, the severity of liver fibrosis, which is the most potent predictor of mortality in NAFLD, is evaluated ${ }^{(16)}$.
The last 10 years have played a crucial role in the evaluation of hepatic fibrosis using elastographic methods ${ }^{(17)}$. These techniques use waves to stimulate hepatic tissue, quantifying elasticity or stiffness as a marker of fibrosis. Starting with elastography and continuing with ARFI and MR elastography, all of these methods have had good and very good results in assessing liver fibrosis. MR elastography has countless advantages, including not being affected by the patient's weight status. However, it has a high price and a low accessibility. Newer ARFI and SSI techniques are effective methods for assessing fibrosis and have shown very good performance in comparative studies. Of note is the ARFI method, with sensitivity and specificity of $80 \%$ and $85.2 \%$, respectively ${ }^{(18)}$.

\section{Treatment of NAFLD associated with diabetes mellitus}

\section{Maintaining ideal body weight}

Maintaining an adequate body weight plays the most important role in preventing NAFLD. Also, the best solution for NAFLD regression already installed in overweight patients with type II diabetes is weight loss, and the safest and most effective method is through an adequate diet. In patients with NAFLD and diabetes, weight loss improved serum levels of insulin, liver function, and quality of life ${ }^{(19)}$. In recent years, pharmacological agents used to 
lower weight in obese patients have been approved: phentermine / topiramate in combination $^{(20)}$, lorcaserin ${ }^{(21)}$ and naltrexone / bupropion in combination ${ }^{(22)}$. These agents are a reasonable therapeutic solution for patients who cannot reach an adequate body weight by changing their lifestyle and diet.

\section{Antidiabetic medication}

Glycemic level control is the primary goal in NAFLD in the presence of type II diabetes mellitus. Recent studies on groups of patients with NAFLD and type II diabetes have shown that a low level of glycosylated hemoglobin was associated with an improvement in hepatic fibrosis over a 2.4 year follow-up period, independent of BMI variations ${ }^{(2.3)}$.

\section{Statins}

In addition to the countless effects of multiple statin-class members, there is evidence that statins can also reduce liver steatosis in NAFLD ${ }^{(24)}$. There is still no definite approval for statins in the prevention and treatment of NAFLD, but further studies are needed to determine the magnitude and duration of potential effects in NAFLD in the presence and absence of type II diabetes mellitus.

\section{The PIVENS study ${ }^{(25)}$}

In this study, there was significant evidence that vitamin $\mathrm{E}$ was superior to placebo in the treatment of non-alcoholic steatohepatitis, and pioglitazone significantly improved the patients' histological appearance.

\section{Future prospects of research}

Routine screening for NAFLD is not recommended for patients with diabetes or those at high risk in the absence of elevated liver enzymes or other evidence of liver disease. This reflects the lack of accurate evidence-based methods for screening this condition and also the uncertainty regarding the effectiveness of NAFLD treatment, once it is diagnosed. As new studies and data on specific antidiabetic therapies, drugs used to lower body weight, or other pharmacologic agents such as statins appear, it is important to constantly evaluate the cost-effectiveness of screening.

Since the rate of progression from simple steatosis to steatosis associated with fibrosis and inflammation is low, screening for simple steatosis is appropriate only if the pharmacological agents used in the treatment would have a low cost and a favorable side effect profile. Considering the high rate of progression of non-alcoholic steatohepatitis to severe liver diseases, including hepatocellular carcinoma or liver failure, the screening focused on steatohepatitis may prove costeffective. For this reason, future research is particularly important.

\section{Abbreviations}

NAFLD - Non-alcoholic fatty liver disease

$\mathrm{NASH}$ - Non-alcoholic steatohepatitis

VLDL - Very low density lipoproteins

TNF- $\alpha$ - tumor necrosis factor $\alpha$

\section{References}

1. Ludwig J, Viggiano TR, McGill DB, Oh BJ. Nonalcoholic steatohepatitis: Mayo Clinic experiences with a hitherto unnamed disease. Mayo Clin Proc 1980; 55: 434-438 (PMID: 7382552)

2. Younossi ZM, Stepanova M, Afendy $M$, et al. Changes in the prevalence of the most common causes of chronic liver diseases in the United States from 1988 to 2008. Clin Gastroenterol Hepatol. 2011;9:524-530.

3. Bedogni G, Miglioli L, Masutti $F$, et al. Incidence and natural course of fatty liver in the general population: the Dionysos study. Hepatology. 2007;46:1387-1391

4. Cortez-Pinto H, Camilo ME, Baptista A, et al. Nonalcoholic fatty liver: another feature of the metabolic syndrome? Clin Nutr. 1999;18:353-358.

5. Stefan N, Häring HU. The metabolically benign and malignant fatty liver. Diabetes 2011;60:2011-7.

6. Reilly ML, Schillie SF, Smith $E$, et al. Increased risk of acute hepatitis $B$ among adults with diagnosed diabetes 
General Reviews

mellitus. J Diabetes Sci Technol 2012;6:858-866.

7. Vernon G, Baranova A, Younossi ZM. Systematic review: the epidemiology and natural history of non-alcoholic steatohepatitis in adults. Aliment Pharmacol Ther 2011;34:274-285.

8. Angulo P. Gl epidemiology: nonalcoholic fatty liver disease. Aliment Pharmacol Ther 2007; 25: 883-889.

9. Tellez-Avila FI, Sanchez-Avila F, Garcia-Saenz-de-Sicilia

M, Chavez-Tapia NC, Franco-Guzman AM, Lopez-Arce G, Cerda-Contreras E, Uribe $M$. Prevalence of metabolic syndrome, obesity and diabetes type 2 in cryptogenic cirrhosis. World J Gastroenterol 2008; 14: 4771-4775

10. Li Y, Wang J, Tang Y, Han X, Liu B, Hu H, et al. (2017) Bidirectional association between nonalcoholic fatty liver disease and type 2 diabetes in Chinese population: Evidence from the Dongfeng-Tongji cohort study.

11. Hickman IJ, Macdonald GA. Impact of diabetes on the severity of liver disease. Am J Med 2007; 120: 829-834.

12. Pessayre D, Fromenty $B$, Mansouri A. Mitochondrial injury in steatohepatitis. Eur J Gastroenterol Hepatol 2004; 16: 1095-1105

13. Nishida T, Tsuji S, Tsujii M, Arimitsu S, Haruna Y, Imano E, Suzuki M, Kanda T, Kawano S, Hiramatsu N, Hayashi N, Hori M. Oral glucose tolerance test predicts prognosis of patients with liver cirrhosis. Am J Gastroenterol 2006; 101: 70-75

14. Sanyal AJ. AGA technical review on nonalcoholic fatty liver disease. Gastroenterology 2002; 123: 1705-1725

15. Nishida T, Tsuji S, Tsujii M, Arimitsu S, Haruna Y, Imano E, Suzuki M, Kanda T, Kawano S, Hiramatsu N, Hayashi N, Hori M. Oral glucose tolerance test predicts prognosis of patients with liver cirrhosis. Am J Gastroenterol 2006; 101: 70-75.

16. Giovanni Targher1, Amedeo Lonardo2,ChristopherD. Byrne et al. Nonalcoholic fatty liver disease and chronic vascular complications of diabetes mellitus, doi: 10.1038/ nrendo. 2017.173.

17. Mark CC Cheah, Arthur J McCullough and George Boon-Bee Goh. Current Modalities of Fibrosis Assessment in Non-alcoholic Fatty Liver Disease. J Clin Transl Hepatol. 2017 Sep 28; 5(3): 261-271.

18. Haixia Liu, Jing Fu Ruixia Hong et al. Acoustic Radiation Force Impulse Elastography for the Non-Invasive Evaluation of Hepatic Fibrosis in Non-Alcoholic Fatty Liver Disease Patients: A Systematic Review \& Meta-Analysis. PLoS One. 2015; 10(7): e0127782.

19. Adams LA, Waters OR, Knuiman MW, et al. NAFLDas a risk factor for the development of diabetes and the metabolic syndrome: an eleven-year follow-up study. Am J Gastroenterol 2009;104:861-7.

20. Xiong GL, Gadde KM. Combination phentermine/topiramate for obesity treatment in primary care: a review. Postgrad Med 2014;126:110-6.

21. Brashier DB, Sharma AK, Dahiya N, et al. Lorcaserin: $A$ novel antiobesity drug. J Pharmacol Pharmacother 2014;5:175-8.

22. Caixàs A, Albert $L$, Capel $I$, et al. Naltrexone sustainedrelease/ bupropion sustained-release for the management of obesity: review of the data to date. Drug Des Devel Ther 2014;8:1419-27.

23. Hamaguchi E, Takamura T, Sakurai M, et al. Histological course of nonalcoholic fatty liver disease in Japanese patients: tight glycemic control, rather than weight reduction, ameliorates liver fibrosis. Diabetes Care 2010;33:284-6.

24. Horlander J, Kwo $P$, Cummings $O$. Atorvastatin for the treatment of NASH (Abstract). Gastroenterol 2001;5:A544.

25. Arun J. Sanyal, M.D. et al, Pioglitazone, Vitamin E, or Placebo for Nonalcoholic Steatohepatitis, N Engl J Med. 2010 May 6; 362(18): 1675-1685. doi:10.1056/ NEJMoa 0907929. 